\title{
Biocompatibility, Osteointegration, Osteoconduction, and Biodegradation of a Hydroxyapatite-polyhydroxybutyrate Composite
}

\author{
Emily Correna Carlo Reis ${ }^{1 *}$, Andréa Pacheco Batista Borges ${ }^{1}$, Cláudio César Fonseca ${ }^{1}$, \\ Mastoby Miguel Martinez Martinez ${ }^{2}$, Renato Barros Eleotério ${ }^{1}$, Gláucia Oliveira Morato ${ }^{1}$ \\ and Paulo Miranda Oliveira ${ }^{3}$ \\ ${ }^{I}$ Departamento de Veterinária; Universidade Federal de Viçosa; Campus Universitário, s/n; 36570-000; Viçosa - \\ MG - Brasil. ${ }^{2}$ Universidade de Córdoba; Cidade Universitária Carrera 6, 76-10; 354; Monteria - Córdoba - \\ Colombia. ${ }^{3}$ Universidade Estadual de Minas Gerais; Escola de Design; Av. Presidente Antonio Carlos, 7545; \\ 31270-010; Belo Horizonte - MG - Brasil
}

\begin{abstract}
In this work, biocompatibility, osteointegration, osteoconductivity, and biodegradation of a hydroxyapatitepolyhydroxybutyrate new composite were evaluated. The composite was implanted in rabbits' bone defects and clinical, radiographic, histological, and histomorphometric data of these animals were compared with those of unfilled defects on the days $8^{\text {th }}, 45^{\text {th }}$, and $90^{\text {th }}$ after surgery. No significant differences existed between the groups for the evaluated clinical parameters. Radiographs showed bone-composite direct contact. Bone formed within the defect, interface and inside the composite. Significant differences were found between the bone and connective tissues percentage within the defect at all dates and at the interface on the $45^{\text {th }}$ day, bone tissue prevailing. Composite's biodegradation signs were evident: giant cells on the surface of composite fragments separated from the original block in the absence of inflammatory infiltrate. These data supported that such composite was biocompatible, biodegradable, osteoconductive and integrate to bone.
\end{abstract}

Key words: biomaterials, bone, biocompatibility, biodegradation, hydroxyapatite-polyhydroxybutyrate composite

\section{INTRODUCTION}

Bone defects are common issues in orthopedics, oncology, and surgical dentistry which make bone substitutes the object of intensive research in the last few years. Ceramics like hydroxyapatite (HA) have been used as bone substitutes, especially in human dentistry, as they are biocompatible, bioactive and osteoconductive, leading to bone regeneration in short periods of time (Borges et al., 2000; Fujibayashi et al., 2003; de Godoy et al., 2005; Lacerda et al., 2007; Sá et al., 2007). Direct contact with bone formed within its porous structure and biodegradation allowed bone tissue to develop and replace HA (Macneill et al., 1999; Borges et al., 2000; Rumpel et al., 2006). However, the use of HA implants for load-bearing functions are limited because they show low modulus of elasticity and fracture toughness, consequently, a brittle material. It is mostly available in granules and bulk forms, but it is not sufficiently stable for use in large defects with load-bearing functions (Kokubo et al., 2003; Sá et al., 2007).

\footnotetext{
*Author for correspondence: emilycarlo@yahoo.com.br
} 
Researchers have been trying to associate HA with different biodegradable polymers to come up with a composite with improved mechanical properties (Knowles et al., 1992; Boeree et al., 1993; Shishatskaya et al., 2006). Polyhydroxybutyrate (PHB) is biocompatible and biodegrades slowly, as needed in bone formation. It is the most studied naturally-occurring polymer in the class of polyhydroxyalkanoates (Knowles et al., 1992; Linhart et al., 2001; Shishatskaya et al., 2006). Such characteristics of biocompatibility and biodegradability have also been found associated with some blends of HA and PHB and these vary according to their origins. Also depending on the proportion between these $\mathrm{HA}$ and PHB, the composite will exhibit good bioactivity and mechanical properties close to cortical bone. These characteristics make it a promising biomaterial for bone substitution in load-bearing areas (Boeree et al., 1993; Wang et al., 2004).

Brazilian researchers tested locally-available biomaterials to develop a new HA-PHB composite (Oliveira, 2005). The cost of this composite was significantly reduced when synthetic sintered HA (HAP-9 $1^{\circledR}$ ) and a PHB obtained from sugarcane were adopted. This work reports a study in rabbits addressing the biocompatibility, osteointegration, osteoconductivity and biodegradation properties of this new composite. This is a first report concerning the biological aspects of this HA-PHB composite to support further researches for a final purpose: the fabrication of prosthesis by prototyping for reconstructive surgeries, as so, a material meant to substitute bone in large defects.

\section{MATERIAL AND METHODS}

\section{Materials}

The composite consisted of $25 \%$ of a bioabsorbable synthetic hydroxyapatite (HAP-91 ${ }^{\circledR}$, JHS Laboratório Químico, Minas Gerais, Brazil) and $75 \%$ polyhydroxybutyrate (PHB), obtained from raw plant material by means of a new local technology. They were made available in a rectangular prismatic format. Just before the surgery, and through the sterile procedures, each prism was cut with a 4-mm diameter trephine attached to a surgical hand drill, under constant washing with saline solution.

\section{Animals and surgical procedure}

All carried-out animal experiments had the approval of the UFV/DVT Ethics Committee which operated in agreement with the Medical Veterinary Professional Ethics Code and Ethical Principles for Animal Research, established by the Brazilian College for Animal Experimentation (COBEA), protocol $n^{\circ} 37$ / 2007. Twenty-four mature New Zealand white rabbits weighing 3 to $3.5 \mathrm{~kg}$ each were equally divided into two groups, the HA-PHB composite (HP) and control groups. Each rabbit received a single dose of ivermectin $(0.4 \mathrm{mg} / \mathrm{Kg})$ and was kept in an individual cage with stock diet and tap water available ad libitum. Immediately prior to the surgery each animal received intramuscular penicillin $(40,000 \mathrm{UI} / \mathrm{kg})$. They were sedated with levomepromazine (2 $\mathrm{mg} / \mathrm{kg}$ ) and anesthetized with intramuscular tiletamine-zolazepam $(30 \mathrm{mg} / \mathrm{kg})$. The animal's forelimb was shaved from the humerus midshaft to the carpus, and an axillary brachial plexus block was made using $1.5 \mathrm{ml}$ of lidocaine. A curved 3$\mathrm{cm}$ skin incision was made aseptically along the lateral side of the elbow joint; fascia and subcutaneous tissues were incised next. The lateral head of the triceps brachial muscle was pushed cranially to allow the exposure of the oleacranon's lateral cortex. A defect was made in the lateral olecranon cortex of the right ulna in each rabbit using a 4-mm diameter trephine attached to a surgical hand drill and under constant washing with sterile saline solution. The composite was positioned inside the defect in animals in the HP group while defects in animals in the control were left empty. Fascia, subcutaneous tissue and skin were sutured using 3-0 nylon. Immediately after the surgery, each rabbit received a single dose of morphine $(2 \mathrm{mg} / \mathrm{kg})$ and $24 \mathrm{~h}$ later another dose of penicillin.

\section{Clinical evaluation}

Each surgical wound was evaluated for dehiscence and infection, the last one noticeable through purulent septic discharge. It was also evaluated for pain, characterized and scored as follows by touching the surgical wound and flexing and extending the elbow joint: 0 - animal showed no reaction to the procedure; 1 - the animal retracted the forelimb under examination; 2 - the animal retracted the forelimb and vocalized or tried to 
move away. Each forelimb was evaluated for lameness: 0 - normal load bearing/ no lameness; 1 load bearing + lameness; 2- lameness without load bearing. Edema was evaluated measuring the limb circumference on the surgical wound. All these were evaluated daily in the first eight days and at the $45^{\text {th }}$ and $90^{\text {th }}$ days after the surgery. Limb circumference was also measured before the surgery.

Mann-Whitney was used to test the differences between control and HP groups for the infection, dehiscence, pain, and lameness variables, looking for differences in days 1,4 , and 8 after the surgery. For the differences between days 1, 4, and 8 after surgery, the Kruskal-Wallis test was used to compare data of each of these variables within each group. Wilcoxon matched-pairs was adopted to test the differences between the circumference data before and after surgery at days 1,4 , and 8 , and Mann-Whitney to test the differences between groups. A $p$ value of less than 0.05 was considered significant for all the statistical tests in this experiment.

\section{Radiographs}

Radiographs in medial-lateral view and skyline view (joint in extreme flexion with the beam tangential to the olecranon) of the olecranon were taken immediately after and at days 8,45 , and 90 after surgery. Defects seen on medial-lateral radiographs were divided into four quadrants (Fig. 1) and each quadrant was graded as being less radiopaque than the adjacent bone, with a radiopacity similar to the adjacent bone or more radiopaque than the adjacent bone. The margin of each quadrant was classified as distinguishable or not distinguishable, hence allowing the evidence of bone-composite integration. Skyline radiographs were used to ascertain the existence of periosteal reaction. Both forelimbs were taken into account but only one of each animal, at random, was considered.

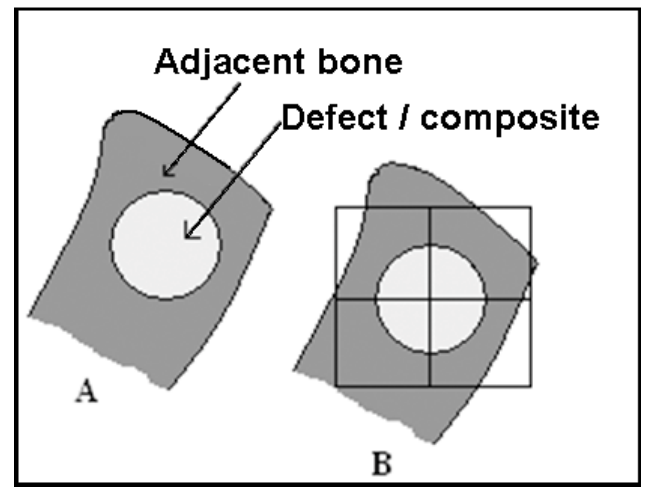

Figure 1 - Schematic drawings, defects seen in medial-lateral radiographs (A) and divided into four quadrants (B).

\section{Histology and histomorphometry}

A $2.5 \%$ sodium thiopental overdose, followed by administered potassium chloride, was instrumental to euthanize four animals in each group at days 8 , 45 , and 90 after surgery. Fragments of both defectcontaining olecranon were collected next; one was fixed in $10 \%$ formalin and the other kept for posterior tests. For light microscopy studies, the formalin-fragments were decalcified under moderate vacuum, during 20 days, in a $\mathrm{pH} 4.5$, sodium citrate buffered, $10 \%$ formic acid solution. Next, they were serially dehydrated in $70^{\circ}, 80^{\circ}$, $90^{\circ}$ and $100^{\circ}$ GL ethanol, cut transversally relatively to the ulna's long axis (Fig. 2), washed in slow-running distilled water during $12 \mathrm{~h}$, kept in xylol for 30 minutes, and infiltrated in paraffin. Histological $5 \mu \mathrm{m}$-thick sections were cut in a rotating microtome provided with disposable blades, mounted on glass slides and stained with toluidine blue in $1 \%$ sodium borate buffer (TB), hematoxylin-eosin (HE) and Gomori trichrome (GT).

For qualitative evaluation, tissues and cells in the entire sample were characterized. For histomorphometry, osteoclasts were counted over 10 sections per animal. Mann-Whitney was used to test the differences between control and the HP groups, and Kruskal-Wallis, followed by Dunn's tests, for paired comparisons between days in each group. With an integrated ocular provided with 
100 points, the proportions of bone marrow, bone and soft tissues were estimated for each animal, by counting the points corresponding to these elements over 5 sections, distributed only at the medullar side of the defect. These data were used to analyze the difference in the formation of bone and soft tissues inside the defect, for each day, using Mann-Whitney. To evaluate the tissues formation inside the composite, the same grid provided with 100 points was superimposed to the composite image only (10 samples per animal). The differences in the formation of soft and bone tissues among the three dates after surgery were evaluated in the HP group using the KruskalWallis test followed by paired comparisons with Dunn's test. The proportions of bone and soft tissues formed at the interface were estimated by counting only the points adjacent to the composite in each horizontal line on a grid provided with 33 vertical and 25 horizontal lines. This was done to analyze the differences in the formation of bone and soft tissues for each day using the MannWhitney test. All results were presented as percentage means and indicated standard deviations.

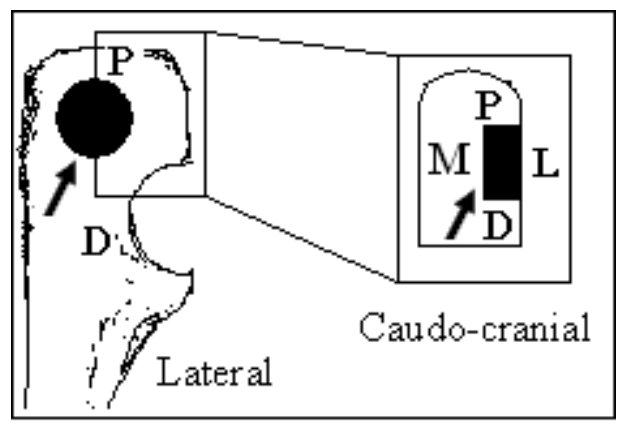

Figure 2 - Schematic drawing, collected fragments showing the defect made by a 4-mm diameter trephine. Lateral and caudal-cranial views. Arrow indicates the defect. M- medullar, L- lateral, P- proximal, D- distal regions.

\section{RESULTS AND DISCUSSION}

\section{Surgery}

A distance from the bone defect wall to the composite was seen during surgery and was due to the use of the same trephine to make the defect (extracting the outside diameter of the trephine) and to cut the composite (leaving it with the inside diameter of the trephine). This space was filled with blood clot and might have influenced the bone formation around the composite. The composites did not break or melt while being cut with the trephine, thus resisting properly to the force applied.

\section{Clinical evaluation}

Most animals showed no pain on the day after the surgery and presented normal load-bearing which was probably related to fact that the surgery caused a small trauma. When existent, they were of grade 1 in both groups, thus in agreement with other studies (Borges et al., 2000; Sá et al., 2007). Dehiscence occurred in both the groups, but only affected the skin suture when happened and was due to the animals' interference, biting the dressings. For dehiscence, infection, pain, and lameness, no significant differences between the groups were found, as well as among the data for days in each group, which suggested that these parameters were due to the surgical manipulation of tissues rather than an effect by the composite (Borges et al., 2000), when they existed. With respect to the circumference values, significant difference was observed for both the groups but only between values from before and the first day after the surgery ( $p$ equal to 0.023 for HP group and 0.01 for control group). No significant variations were found between the groups for the values of circumference differences in any of the evaluated days, suggesting edema as a result of tissue manipulation during surgery.

\section{Radiographs analysis}

Similar data for each group were visible on radiographs taken immediately after the surgery and on $8^{\text {th }}$ day. All quadrants in both the groups 
showed distinguishable margins and the control quadrants were less radiopaque than the adjacent bone (Fig. 3A) and the HP were similar (Fig. 3B) to the adjacent bone. Hydroxyapatite showed the high radiopacity compatible with its chemical composition, $\mathrm{Ca}_{10}\left(\mathrm{PO}_{4}\right)_{6}(\mathrm{OH})_{2}$ (Sá et al., 2007). A radiolucent circle was observed around the composite (Fig. 3B), which matched the distance from the defect wall to the composite as seen during surgery, filled by blood clot, an unmineralized tissue, and also at the eighth day, probably due to the invasion by soft tissues that took part in bone regeneration (Sá et al., 2007).

At 45 days, $37.5 \%$ of the quadrants in the control group had a radiopacity similar to the adjacent bone that increased to $58.3 \%$ at 90 days, with most quadrant margins undistinguishable, an indication of normal bone regeneration. The radiopacity in the HP group remained similar to that of the surrounding bone at 45 and 90 days, in all quadrants, when most margins were undistinguishable. Radiolucent circles were not seen in either case. Direct bone contact to the composite was also observed (Fig. 3D), which suggested osteointegration (Doyle et al., 1991; Knowles et al., 1992; Luklinska and Bonfiled, 1997). Periosteal reactions analyzed in skyline views were seen in 3 and 2 forelimbs, respectively in the control and HP groups at days 45 and 90 only, which could be related to new bone formation (Miranda et al., 2005).

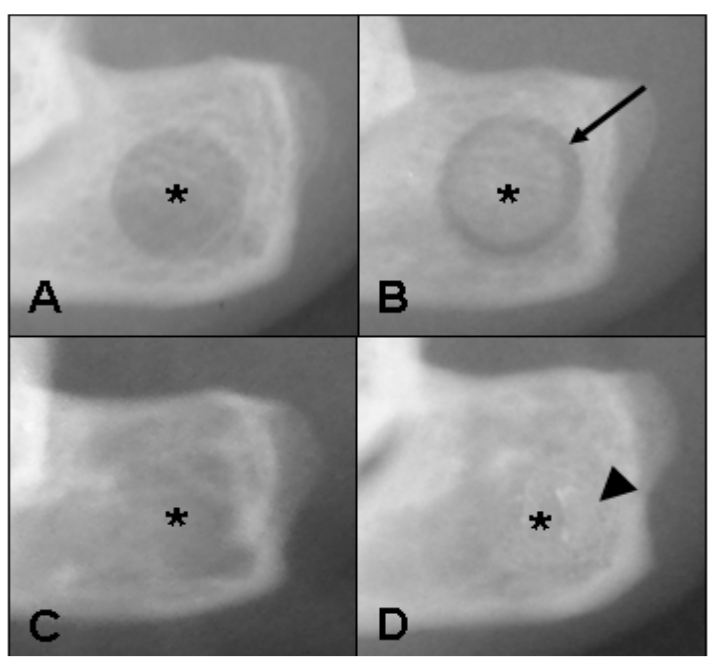

Figure 3 - Medial-lateral radiographs of the defects made in the olecranon of rabbits' ulna. A- Defect $\left.{ }^{*}\right)$ in the control group, no composite, 8 days after surgery. B- HP group, hydroxyapatitepolyhydroxybutyrate composite $(*), 8$ days after surgery. Arrow indicates radiolucent circle. C- Defect $(*)$ in the control group, 45 days after surgery. D- HP group, hydroxyapatite-polyhydroxybutyrate composite (*), 45 days after surgery. Arrows head indicates bone-composite contact.

\section{Histological and histomorphological analysis}

During the standard, aqueous staining with toluidine blue, the composite separated from the bone at the moment the water contacted the histological sections from all the analyzed dates and moved away. Such separation showed that the composite-tissues interface was weak, but the event must be considered under the composite properties of hydrophilicity and biodegradation. This composite is known to be hydrophilic, and this increases in intensity along with the HA content, causing the water bonding and the ensuing pulling effect (Ito et al., 2005;
Shishatskaya et al., 2006). In a study on the interface structure of another hydroxyapatitepolyhydroxybutyrate composite, Luklinska and Bonfield (1997) reported that the PHB was the phase being degraded when analyzing the surfaces of a similar separation. They concluded that such degradation caused bone and composite to come apart, not a failure at the interface. Apparently, the same happened in the present work.

In the control group, bone regeneration proceeded normally with most defect being occupied by vascularized, dense connective tissue on day 8 . The defect wall was then easily identifiable, new 
trabecular bone arising from the medullar region (Fig. 4A) and fibro-cartilaginous tissue seen at some points. This new trabecular bone was characterized by thin trabeculae surrounded by a large number of active osteoblasts, showing evident nucleoli (Fig. 4B). At 45 days, a more organized bone tissue was evident in the medullar region. On the $90^{\text {th }}$ day the lateral cortex had been reestablished, along with its adjacent mature trabecular bone.

In the HP group, on every observation date, tissues were very similar to those in the control group, with no inflammatory infiltrate of any kind, fully attesting to the composite's biocompatibility (Linhart et al., 2001; Volova et al., 2003). Within the defect, on all evaluation dates, more bone than connective tissue had been formed (Table 1), thus showing that the composite did not impair bone regeneration ( $p$ value of less than 0.001 for $8^{\text {th }}$ and equal to 0.031 and 0.004 for $45^{\text {th }}$ and $90^{\text {th }}$ day after surgery, respectively). The defects were not of a critical size, defined as having a size that precluded spontaneous bone regeneration (Macneill et al., 1999), thus, more bone tissue in the HP group than in control group wasn't expected. This was not the subject of this study. On the $8^{\text {th }}$ day, more connective tissue was found at the interface (Table 2), a $p$ value of less than 0.001 . In the medullar region, mainly new bone had been formed in direct contact with the composite (Fig. 5A), and more vascularized, dense connective tissue was visible on the interface in the proximal and distal sides of the composite (Fig. 5B); the last of these was distinguishable on radiographs as a radiolucent circle (Fig. 3D).

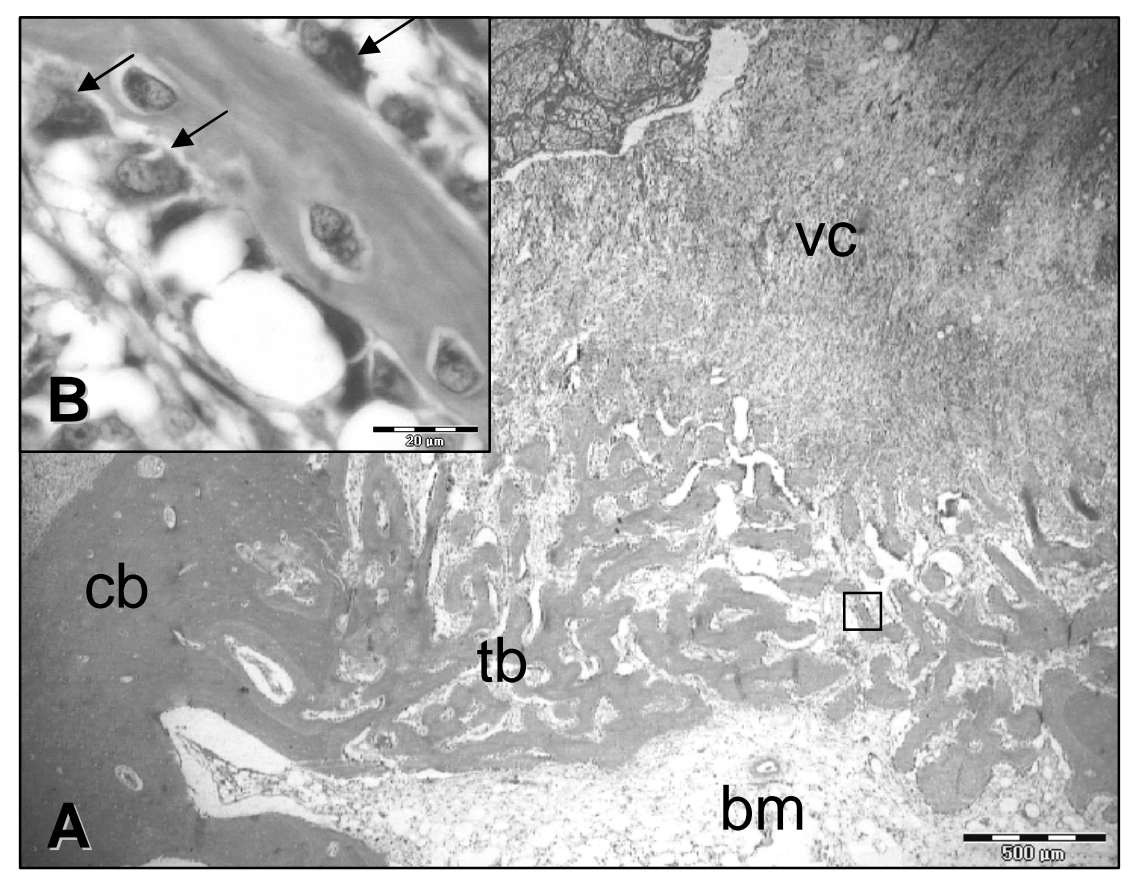

Figure 4 - Histological view of the defect in the control group, $8^{\text {th }}$ day after surgery. A- Cortical bone distal to the defect (cb), trabecular bone (tb) in the medullar region, bone marrow (bm) and vascularized, dense connective tissue (vc). HE, bar $=500 \mu \mathrm{m}$. B- Detail, marked area in A: new trabeculae and active osteoblasts (arrows). HE, bar $=20 \mu \mathrm{m}$.

Table 1 - Means (\%) and standard deviations of bone tissue and connective tissue within the defect made in rabbit's olecranon. Sections made 8,45 , and 90 days after composite $\left(25 \%\right.$ de HAP-9 ${ }^{\circledR}$ and $75 \%$ de PHB) implantation.

\begin{tabular}{lcc}
\hline Day & Bone Tissue (\%) & Connective Tissue(\%) \\
\hline 8 & $47,3 \pm 7,7 \mathrm{a}$ & $10,2 \pm 7,0 \mathrm{~b}$ \\
45 & $42,0 \pm 10,8 \mathrm{c}$ & $0 \mathrm{~d}$ \\
90 & $41,3 \pm 6,7 \mathrm{e}$ & $6,5 \pm 7,0 \mathrm{f}$ \\
\hline
\end{tabular}

Different letters in the same line indicate significant statistical difference by the Mann-Whitney test $(\mathrm{p}<0,05)$. 
Possibly, such difference on tissues formation was influenced by the distance from the defect wall to the composite, which when existent allowed some composite mobility and soft tissue ingrowth prior to bone formation (Saba-chujfi et al., 2002; Grinfon, 2005). Such mobility is known to affect negatively the development of blood vessels and consequently bone formation (Grinfon, 2005). More bone at the medullar region could have also been influenced by the presence of bone marrow in this space, a known source of osteoprogenitor cells (Boer et al., 2003). On the $45^{\text {th }}$ day, more mature bone was visible at the interface (Table 2), with a $p$ value of less than 0.001 , in direct contact with the composite (Fig. 6A), a clear indication that osteointegration was in progress. This observation mimiced those reported in works using different hydroxyapatites, alone or in association with PHB (Doyle et al., 1991; Luklinska and Bonfiled, 1997; Borges et al., 2000; Sá et al., 2007). On the $90^{\text {th }}$ day, this significant difference between the bone and connective tissues seen on the $45^{\text {th }}$ day wasn't found (Table 2), a direct contact of bone and composite had been established but also of the composite to vascularized connective tissue, probably due to what has just been explained.

On the $90^{\text {th }}$ day, bone $(1.8 \% \pm 6.7)$ and vascularized connective tissues $(1.5 \% \pm 5.2)$ were seen projecting into the composite (Fig. 6B) from the adjacent structures (bone and bone marrow), a confirmation that this composite was osteoconductive.

Table 2 - Means (\%) and standard deviation of bone and connective tissues at the interface with the composite made of $25 \%$ of HAP- $91^{\circledR}$ and $75 \%$ de PHB, 8,45 , and 90 days after the implantation.

\begin{tabular}{lcc}
\hline Day & Bone Tissue (\%) & Connective Tissue(\%) \\
\hline 8 & $16,4 \pm 8,3 \mathrm{a}$ & $83,6 \pm 8,3 \mathrm{~b}$ \\
45 & $71,8 \pm 6,1 \mathrm{c}$ & $0,9 \pm 1,6 \mathrm{~d}$ \\
90 & $54,6 \pm 27,6 \mathrm{e}$ & $34 \pm 29,0 \mathrm{e}$ \\
\hline
\end{tabular}

Different letters in the same line indicate significant statistical difference by the Mann-Whitney test $(\mathrm{p}<0,05)$

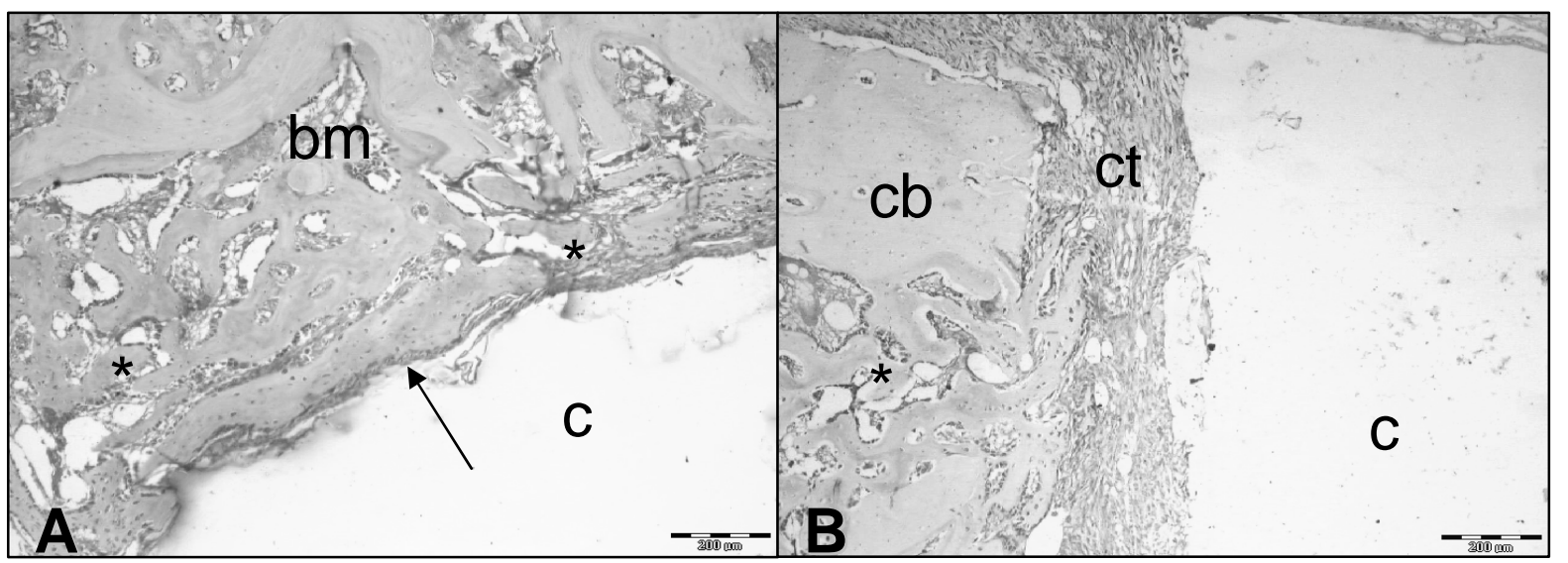

Figure 5 - Histological view of the defect in the HP group, with hydroxyapatite-polyhydroxybutyrate composite (c). A - New trabecular bone $(*)$ in the medullar region and direct bonecomposite contact (arrow), $8^{\text {th }}$ day after surgery. bm: bone marrow. Toluidine blue, bar $=$ $200 \mu \mathrm{m}$. B - Eighth day interface, proximal side of the composite shows cortical bone (cb), connective tissue (ct) between cortical bone and composite, and new trabecular bone (*). Toluidine blue, bar $=200 \mu \mathrm{m}$.

The distance from the defect wall to the composite might have delayed osteoconduction, as a tight and immobile contact of both was a prerequisite for it to occur (Boer et al., 2003). The trabeculae formed in the composite were seen close to the medullar region (Fig. 6B), an event clearly influenced either by the bone marrow (more osteoprogenitor cells than cortical bone at the proximal/distal sides) or 
by the early bone-composite contact already estasblished on the $8^{\text {th }}$ days (Boer et al., 2003), or by these two.

The osteointegration and osteoconduction here being reported are in agreement with previous works, in which they have been identified as new bone developed into the composite pores on the surface of the hydroxyapatite granules. This is followed by biodegradation of the PHB matrix, resulting in new pores, where more hydroxyapatite crystallites and new bone will be formed. Thus, gradually, the composite can be replaced by bone (Luklinska and Bonfiled, 1997; Davies and Baldan, 1997; Fuijibayashi et al., 2003).

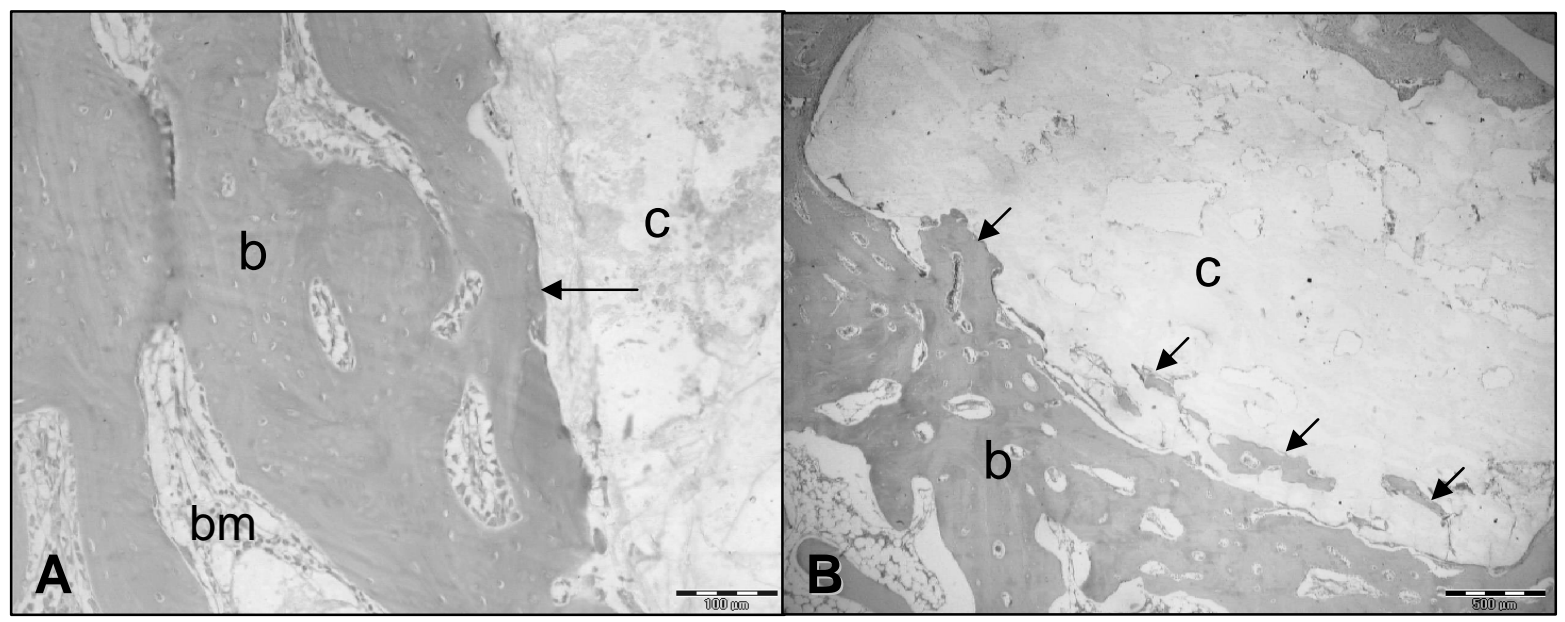

Figure 6 - Histological view of the defect in the HP group, with hydroxyapatite-polyhydroxybutyrate composite (c). A- Mature bone (b) in direct contact (arrow) with the composite, on the $45^{\text {th }}$ day. bm: bone marrow. HE, bar $=100 \mu \mathrm{m}$. B- Bone tissue projected (arrows) inside the composite and mature bone (b) at the medullar region, $90^{\text {th }}$ day. $\mathrm{HE}$, bar $=500 \mu \mathrm{m}$.

The mean number of osteoclasts estimated did not differ between the groups, but in both the groups a significant difference was found in data for the $8^{\text {th }}$ and $90^{\text {th }}$ days (Table 3), with a $\mathrm{p}$ value of 0.009 and 0.032 for HP and control groups, respectively. Such observation substantiated that a more mature bone existed on the last observation date. It would be important to note that osteoclasts on the $8^{\text {th }}$ day were present in the region of new trabeculae formation and, on the $90^{\text {th }}$, they were restricted to the interface in the HP group. These cells are known to take part in bone remodeling and resorption, as well as in the biodegradation of hydroxyapatite (Borges et al., 2000; Rumpel et al., 2006). HA biodegradation probably occurred in the present case. Tissues formation within the composite and composite fragments separated from the original block point to active composite degradation. These fragments were surrounded by the bone and also by the connective tissue (Fig. 7) at the lateral surface of the implant where, in the absence of any inflammatory infiltrate, multinucleated giant cells contacted them (Fig. 7).

Table 3 - Means and standard deviation of osteoclasts number in experimentally-made defects 8, 45, and 90 days after the composite (25\% de HAP-91 ${ }^{\circledR}$ and $75 \%$ de PHB) implantation (HP group), and without it (control group).

\begin{tabular}{lcc}
\hline Day & HP & C \\
\hline 8 & $20,2 \pm 9,7$ a A & $27,7 \pm 3,5$ a C \\
45 & $13,7 \pm 5,0$ b AB & $10,7 \pm 11,5$ b CD \\
90 & $2,7 \pm 2,4$ c B & $1,3 \pm 1,5$ c D
\end{tabular}

Same minuscule letters in the same line indicate absence of significant statistical difference by the Mann-Whitney test $(\mathrm{p}<0,05)$. Different capital letters in the same column indicate significant statistical difference by the Kruskal-Wallis test $(\mathrm{p}<0,05)$. 


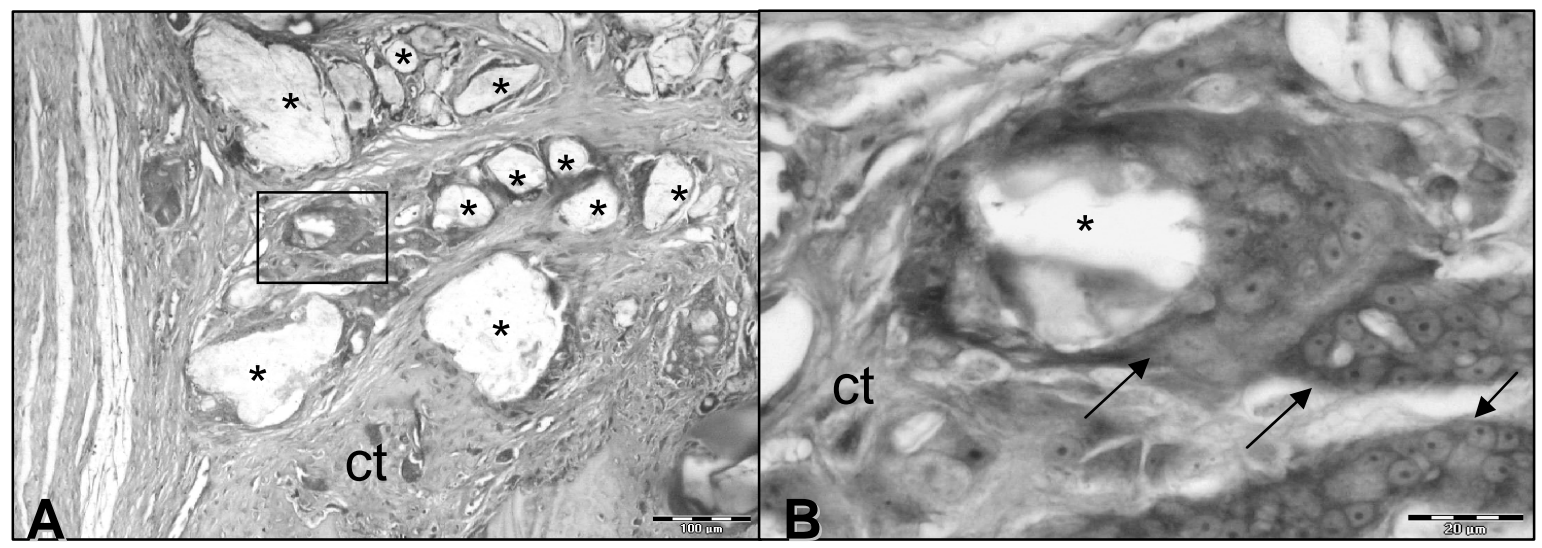

Figure 7 - A- Lateral region of the defect on the 90th day. Composite fragments (*) separated from the original block within vascularized, dense connective tissue (ct) covering the defect's lateral surface. Toluidine blue, bar $=100 \mu \mathrm{m}$. B- Detail, marked area in A: multinucleated giant cells (arrows) surround composite fragments, no inflammatory infiltrate. Toluidine blue, bar $=20 \mu \mathrm{m}$.

This was additional evidence that the composite was degraded, as these cells have been reported to actively participate in PHB and HA biodegradation (Borges et al., 2000; Volova et al., 2003; Rumpel et al., 2006).

The HAP-9 $1{ }^{\circledR}$-PHB composite showed good potential for clinical applications as it was shown biocompatible, osteoconductive, integrate to bone and could be degraded in vivo. These basic properties show good perspectives for more studies, first on its mechanical properties followed by on implants production, clinical evaluations as bone substitute in large segmental defects in long bones, and as scaffold for tissue engineering.

\section{ACKNOWLEDGEMENTS}

The authors thank Dr. Sheyla Maria de Castro Máximo Bicalho from JHS Laboratório Químico for the composite and Coordenação de Aperfeiçoamento de Pessoal de Nível Superior (CAPES) for the Master's scholarship to Emily Correna Carlo Reis.

\section{RESUMO}

A biocompatibilidade, osteointegração, osteocondução e biodegradação de um novo compósito de hidroxiapatita e polihidroxibutirato foram avaliados. O compósito foi implantado em defeitos ósseos em coelhos e dados clínicos, radiográficos, histológicos e histomorfométricos foram comparados aos de defeitos não preenchidos aos 8, 45 e 90 dias após a cirurgia. Não foram observadas diferenças significantes entre os grupos para os parâmetros clínicos avaliados. Contato direto entre osso e compósito foi observado nas radiografias. Tecido ósseo se formou dentro do defeito, interface e dentro do compósito. Foram observadas diferenças significativas entre a porcentagem dos tecidos ósseo e conjuntivo dentro do defeito em todas as datas de avaliação e na interface aos 45 dias, com predominância do tecido ósseo. Sinais de biodegradação foram observados: células gigantes na superfície de fragmentos do compósito separados do bloco original, na ausência de infiltrado inflamatório. Os dados permitem concluir que o compósito é biocompatível, biodegradável, osteocondutor e se integra ao tecido ósseo.

\section{REFERENCES}

Boer, F.C., Wippermann, B.W., Blokhuis, F.J., Patka, P., Bakker, F.C and Haarman, H.J.T.M. (2003), Healing of segmental bone defects with granular porous hydroxyapatite augmented with recombinant human osteogenic protein-1 or autologous bone marrow. J Orthop Res, 21 (3), 521-528.

Boeree, N.R., Dove, J., Cooper, J.J., Knowles, J. and Hastings, G.W. (1993), Development of a degradable composite for orthopaedic use: mechanical evaluation of an hydroxyapatite-polyhydroxybutyrate composite material. Biomaterials, 14 (10), 793-796. 
Borges, A.P.B., Rezende, C.M.F., Ribeiro, M.F.B., Melo, E.G. and Neto, P.I.N. (2000), Hidroxiapatita sintética como substituto ósseo em defeito experimental provocado no proximal da tíbia de cão: aspectos à microscopia de transmissão Arquivo Brasileiro de Medicina Veterinária e Zootecnia, 52 (6), 616-620.

Davies, J.E. and Baldan, N. (1997), Scan. electron microscopy of the bone-bioactive implant interface. $J$ Biomed Mater Res 36 (4), 429-440.

de Godoy, J.L., Otta, E.K., Miyazaki, R.A., Bitencourt, M.A. and Pasquini, R. (2005) Central venous access through external jugular vein in children submitted do bone marrow transplantation. Braz, Arch Biol Tech 48 (1)m 41-44.

Doyle, C., Tanner, E.T. and Bonflield, W. (1991), In vitro and in vivo evaluation of polyhydroxybutyrate and of polyhydroxybutyrate reinforced with hydroxyapatite. Biomaterials, 12 (9), 841-847.

Fujibayashi, S., Masashi, N., Kim, A.M., Kokubo, T. and Nakamura, T. (2003), A comparative study between in vivo bone ingrowth and in vitro apatite formation on $\mathrm{Na} 2 \mathrm{O}-\mathrm{CaO}-\mathrm{Si} 2$ glasses. Biomaterials, 24 (8), 1349-1356.

Griffon, D.J. Fracture healing. In: Johnson, A.L., Houlton, J.E.F. and Vannini, R. (Eds.) AO Principles of Fracture Management in the dog and cat. (2005). New York, Thieme, p. 72-97.

Ito, Y., Hasuda, H., Kamitakahara, A. M., Ohttsuki, C. Tanihara, M., Kang, I.K. and Kwon, O.H. (2005), A composite of Hydroxyapatite with electrospun biodegradable nanofibers as a tissue engineering material. J Biosci Bioeng, 100 (1), 43-49.

Knowles, J.C., Hastings, G.W., Ohta, H., Niwa, S. and Boeree, N. (1992), Development of degradable composite for orthopaedic use: in vivo biomechanical of two bioactive degradable composites based on the polyhydroxybutyrate polymer. Biomaterials, 13 (8), 491-496.

Kokubo, T, Kim, H.M. and Kawashita, M. (2003), Novel bioactive materials with different mechanical properties. Biomaterials, 24 (13), 2161-2175.

Lacerda, K.A., Lameiras, F.S. and Silva V.V. (2007) Quantification of iodine in porous hydroxyapatite matrices for application as radioactive sources in brachytherapy. Braz Arch Biol Tech 50 (4), 707-711.

Linhart, W., Lehmann, W., Siedler, M., Peters, F., Shilling, A.F., Schwarz, K., Amling, A., Rueger, J.M. and Epple, M. (2001), Composites of amorphous calcium phosphate and poly(hydroxybutyrate) and poly(hydroxybutyrateco-hydroxyvalerate) for bone substitution: assessment of the biocompatibility. J Biomed Mater Res, 54 (2), 162-171.
Luklinska, Z.B. and Bonfield, W. (1997), Morphology and ultrastructure of the interface between hydroxyalatite-polyhydroxybutyrate composite implant and bone. J Mater Sci-Mater M, 8 (6), 379383.

Macneill, S.R., Cobb, C.M., Rapley, J.W., Glaros, A.G. and Spencer, P. (1999), In vivo comparison of synthetic osseous graft materials. A preliminary study, J Clin Periodontol. 26 (4), 239-245.

Miranda, E.S., Cardoso, F.T.S., Medeiros, J.F.F., Barreto, M.D.R., Teixeira, R.M.M., Wanderley, A. and Fernandes, K.E. (2005), Estudo experimental comparativo no uso de enxerto ósseo orgânico e inorgânico no reparo de fraturas cirúrgicas em rádio de coelhos. Acta Ortopédica Brasileira, 13 (5), 245248.

Oliveira, P.M. (2005), Desenvolvimento e caracterização de compósitos de matriz polimérica de PHB reforçados com HAP- $91^{\circledR}$. Master's Thesis, Universidade Federal de Ouro Preto, Minas Gerais, Brasil.

Rumpel, E., Wolf, E., Kauschke, E., Bienengrber, V., Bayerlein, T., Gedrange, T. and Proff, P. (2006), The biodegradation of hydroxyapatite bone graft substitutes in vivo, Folia Morphology. 65 (1), 43-48.

Sá, M.J.C., Rezende, C.M.F., Silva junior, V.A., Garcia, H.C., Griffon, D.J. and Silva, V.V. (2007), In vivo behavior of zirconia-hydroxyapatite ( $\mathrm{ZH})$ ceramic implants in dogs: a clinical, radiographic, and histological study. J Biomater Appl, 22 (1), 5-31.

Saba-chujfi, I. E., Pereira, S.A.S. and Saba, M.E.C. (2002), Opções cirúrgicas na terapia da bolsa periodontal. In: Cardoso, R.J.A. and Gonçalves, E.A.N. Periodontia, Cirurgia, Cirurgia para implantes. $20^{\circ}$ Dentistry International Congress of São Paulo. São Paulo: Artes Médicas Divisão Odontológica, 121-136.

Shishatskaya, E.I., Khlusov, I.A. and Volova, T.G. (2006), A hybrid PHB-hydroxyapatite composite for biomedical application: production, in vitro and in vivo investigation. JBiomatl Sci-Polym E, 17 (5), 481498.

Volova, T., Shishatskaya, E., Sevastianov, V., Eremov, S. and Mogilnaya, O. (2003), Results of biomedical investigations of PHB and PHA/PHV fibers, Biochem Eng $J, 16$ (2), 125-133.

Wang, Y.W., Wu, Q. and Chen, G.Q. (2004), Attachment, proliferation and differentiation of osteoblasts on random biopolyester poly(3hydroxybutyrate-co-3hydroxyhexanoate) scaffolds. Biomaterials, 25 (4), 669-675. 